ISSN 1991- 8690

website : http:// jsci.utq.edu.iq

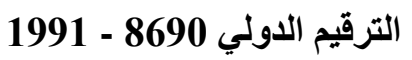

Email:utjsci@utq.edu.iq

\title{
Synthesis, Characterization, and study of the Spectral and Electronic Properties of a New Azo Dyes Compounds
}

\begin{abstract}
Hasanain A S. A Majeed
Department of Chemistry - College of Education - Basrah University-Basrah - Iraq

\section{Abstract}

In this study two new azo dyes were prepared from 4-acetaminophenol with 4-amino-N-2-pyrimidinylbenzenesulfonamide \& 4-amino-N-(5-methyl-3-isoxazolyl)-benzenesulfonamide were prepared. The prepared by Fox method, the azo dyes were identified by IR- spectrophotometer, UV-visible spectroscopy and elemental analysis $(\mathrm{CHN})$. The absorption spectra of the azo dye was recorded with wavelength in the range (360-600) $\mathrm{nm}$ in universal buffer solution of different $\mathrm{pH}$ values. From these spectra, the ionization and protonation constant were calculated by using the half height method. It found that the value of the ionization constant $(\mathrm{pKa})$ closely which interpret the ionization of the hydroxyl group. Theoretical calculations for azo dyes were studied by quantum chemical calculations. The optimized structures of the azo dyes were obtained by molecular mechanics (MM+), and then further geometry optimization was carried out by the semiempirical molecular orbital theory at the level of AM1 of the theory. Study Shown, the configuration II more stable because of have high energy gap $\Delta \mathrm{E}$ and high stability. Also the dipole moment, heats of formation, molecular orbitals energy of HOMO and LUMO were calculated.
\end{abstract}

KeyWord: Azo dyes Derivative from acetaminophenol, Electronic Properties, ionization at protonation constant Spectral studies. Electronic Properties

تم في هذه الدراسة تحضير صبغتين آزوينتين جديدتين (I, II)مشنقة من مركبات السلفا الدوائية مع المركب 4 - أستيمينوفينول بطريقة فوكس. شخصت الصبغات المحضرة بواسطة طيف الأشعة تحت الحمراء طيف الأشعة المرئية وتحليل الدقيق للعناصر • وقد تمت دراسة تأثير الأس الهيدروجيني في أطياف الأمنصاص الإكترونية للصبغات المحضرة في المنطقة المرئية بمدى من الاطوال الموجية (600-360) وباستعمال محلول منظم ذو قيم أس هيدروجيني مختلفة ومن هذه الأطياف نم الأن حساب ثابت نأين مجموعة الهيدروكسيل وثابت برتتة النيتروجين باستخدام طريقة منتصف الارتفاع • فقد وجد تقارب كبير في قيم ثابت تأين مجموعة الهيدروكسيل ـ أضافة لذلك تم في هذا البحث دراسة نظرية الخصائص والصفات التركيبية والاككترونية للصبغات ألازوية (II) بواسطة كيمياء الكم لأول مرة ـ موائمة التراكيب انجزت اولا

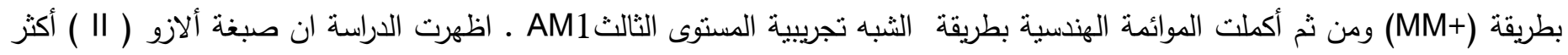
استقرارا من صبغة الازو (ا)، وكما تم حساب حرارات التكوين ،ا لعزم ثنائي القطب ، طاقة الاوربيتال الجزيئية HOMO LUMO وقيمة 


\section{Introduction}

Azo dyes contain one or more azo groups (- N $=\mathrm{N}-$ ) which are linked to $\mathrm{SP}^{2}$ hybridized carbon atoms, based on the number of such groups [1]. The dyes known as monoazo dyes have only one $(-\mathrm{N}=$ $\mathrm{N}$-) group while diazo and triazo dyes contain two and three $(-\mathrm{N}=\mathrm{N}-)$ group, respectively. The azo groups are generally connected to benzene and naphthalene rings, but can also be attached to aromatic heterocycles or enolizable aliphatic groups [2-3].

Synthetic dye manufacturing started in 1856, when the English chemist W.H. Perkin, in an attempt to synthetic quinine, obtained instead a bluish substance with excellent dyeing properties that later became known as aniline purple, Tyrian purple or mauveine. Perkin 18 years old patented his invention and set up a production line. This concept of research and development was soon to be followed by others and new dyes began to appear on the market, a process that was strongly stimulated by Kekules discovery of the molecular structure of benzene in 1865 . In the beginning of the $20^{\text {th }}$ century, synthetic dyestuffs had almost completely supplanted natural dyes [4-5].

The synthesis of most azo dyes involves diazotization of a primary aromatic amine, followed by coupling with one or more nucleophilic aromatic compound such as an aryl amine or a phenol.

Azo dyes are the most important class of industrial dyes, both in number and amount. In addition, azo dyes have found wide application in dyeing wool, polyamide fiber, semi conductivity textile and food industries [6-9]. The computational chemistry are to characterize and predict the structure and stability of chemical systems, to estimate energy differences between different states, and to explain reaction pathways and mechanisms at the atomic level and bond geometries, angles, torsion, atomic charges $^{(10-11)}$.

In the present study a new tow azo compounds were prepared and Identification by IR, U. VVisible spectroscopy, elemental analysis (CHN) and study of the Structure, Electronic Properties and relative stabilities properties were studied.

\section{Experimental}

A- Reagent

Methanol, 4- acetaminophenol, 4-amino-N-2pyrimidinyl-benzenesulfonamide and 4-amino-N(5-methyl-3-isoxazolyl) benzensulfonamide from ( Fluka Co.), sodium hydroxide, sodium nitrite, hydrochloric acid, Ethanol from (Merck Co.), were purified before using [12]. Physical measurements, IR spectra were recorded on a Buck Scientific Model 500. IR spectrophotometer using a $\mathrm{KBr}$ disc in the range $(600-4000) \mathrm{cm}^{-1}$. Absorption Spectra in Methanol with the concentration of $\left(8 \times 10^{-5}\right) \mathrm{M}$ were determined on a U-1500- HITACH UVVisible spectrophometer. The melting Point (M.P) of the compounds were determined with a 9300 Model - Electro thermal melting point. IR, UVVisible spectrophotometer and melting point was performed by Chemistry Department - Education College - Basrah University. Elemental analysis ( $\mathrm{CHN}$ ) of the compounds were determined with Euro Vector EA 3000A Italy was performed by albayt university.

\section{A- Methods \\ Synthesis of the Azo Dyes}

The above azo dyes were prepared by a method similar to that described by Fox [13]. In the present method the dyes (I, II) were prepared as following:

1. (0.006mole, $1.5017 \mathrm{~g})$ of amine (4-amino$\mathrm{N}$-2-pyrimidinyl-benzenesulfonamide) or $(0.006 \mathrm{~mole}, 1.5197 \mathrm{~g})$ of amine (4-amino$\mathrm{N}$-(5-methyl-3-isoxazolyl)

benzenesulfonamide) was dissolved in $2.1 \mathrm{ml}$ of conc. $\mathrm{HCl}$ and then $5 \mathrm{ml}$ of distilud water was added, the mixture was stirrer and kept in ice bath.

2. $0.456 \mathrm{~g}$ of $\mathrm{NaNO}_{2}$ was dissolved in about $10 \mathrm{ml}$ of distilud water and kept in ice bath.

3. Diazonium salt was prepared by adding sodium nitrite solution in step (2) dropwise to the cold solution of amine in the step (1) with stirring and keeping the temperature (0-5) ${ }^{0} \mathrm{C}$.

4. Coupler was prepared by dissolving (0.006mole, $0.9070 \mathrm{~g})$ of both (4- 
5. acetaminophenol) in $25 \%$ sodium hydroxide solution and keeping in ice bath.

6. The diazonium salt was added drop wisely to the couplers with constant stirring, keeping the temperature below $5^{0} \mathrm{C}$; the dyes were neutralized with dilute hydrochloric acid solution.
7. The resulting crudes were recrystallized from methanol the purity of the resulting azo dyes have been characterized by elemental analysis and IR, UV spectra. Analytical and physical data of the azo dyes (I and II) are listed in Table ( 1 ). The structure of the azo dyes in figure 1 .

Form $=\mathbf{I}$

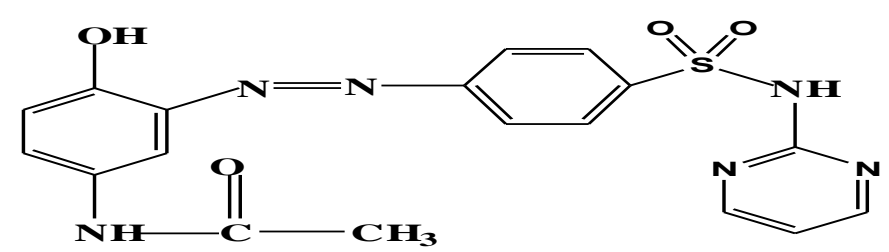

Form $=\mathbf{I I}$

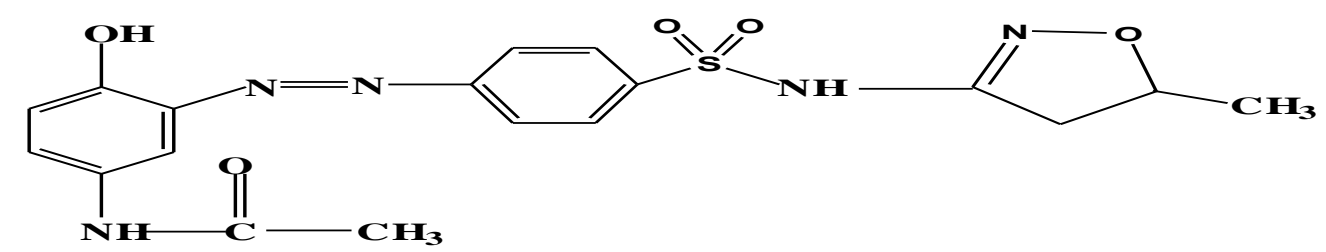

Figure 1 :Chemical structures of the prepared azo dyes ( I and II ), I=4-Acetaminophenol-[2-(4-Azo)]-N-2pyrimidinyl-benzenesulfonamide, II= 4-Acetaminophenol-[2-(4-Azo)]-N-(5-methyl-3-isoxazolylbezenesulfonamide.

\section{B- Analytical Study}

\section{1- Preparation of Buffer Solutions of acetate}

A series of buffer solutions covering the range of $\mathrm{pH}$ values (0.65 to 5.2) was prepared by mixing $(25 \mathrm{ml})(1 \mathrm{M})$ sodium acetate with $(37.5 \mathrm{ml}$, $30.0 \mathrm{ml})$ hydrochloride acid $(1 \mathrm{M})$ to give $\mathrm{pH}(1.0$, 1.5) respectively. The $\mathrm{pH}$ values of the buffer solutions were checked by aid of a pH-meter ${ }^{(14-15)}$.

\section{2- Universal Buffer Solutions:}

A series of buffer solutions covering the range of $\mathrm{pH}$ values ( 2 to 12 ) was prepared as recommended by Britton and Rhobinson ${ }^{(15)}$ with modification involving titration of $50 \mathrm{ml}$ of the mixture $(0.04 \mathrm{M}$ with respect to boric, acetic and phosphoric acids) with $0.2 \mathrm{M}$ sodium hydroxide to the desired $\mathrm{pH}$ and then making with water up to $250 \mathrm{ml}$ so as to keep the ionic strength almost constant at all $\mathrm{pH}$ values. The $\mathrm{pH}$ values of the buffer solutions were checked by aid of a $\mathrm{pH}-$ meter $^{(16)}$.

\section{3- Solutions of Dyes:}

The $0.001 \mathrm{M}$ dye solution was prepared by dissolving the $(\mathrm{I}=0.0206 \mathrm{gm}),(\mathrm{II}=0.0208 \mathrm{gm})$ of the dye in the mixture of proper volumes of ethanol to the desired $(50 \mathrm{ml})$ Solutions of Dyes.

\section{4- Spectrophotometric Methods for the Determination of pK Values of Azo Dyes:}


The absorption spectra of the azo-dyes under investigation were scanned within the wavelength range $(360-600) \mathrm{nm}$ in universal buffer solutions covering the range of $\mathrm{pH}$-values $\quad(1.0-12)$ for this purpose a known volume $(0.4 \mathrm{ml})$ of the aqueous solution of the azo compounds $\left(10^{-3} \mathrm{M}\right)$ was added in $5 \mathrm{ml}$ volumetric flask and then made up to the mark with buffer solution. The spectra were obtained at room temperature figure 2 . The study carried out in this part considered mainly two points:

a. The effect of $\mathrm{pH}$ on absorption spectra on the azo dyes.

b. Determination of the ionization constant $\left(\mathrm{pK}_{\mathrm{a}}\right)$ of the hydroxyl group and the protonation constant $\left(\mathrm{pK}_{\mathrm{p}}\right)$ of the nitrogen atom. Half height method ${ }^{(17-19)}$ was used for the determination of $\mathrm{pK}$ values. This method depends on the fact that the limiting absorption $\left(\mathrm{A}_{l}\right)$ represents complete conversion of one form of the compound to the other. Since $\mathrm{pK}$ is equal to $\mathrm{pH}$ at which the two forms exist in equivalent amount, then the $\mathrm{pH}$ corresponding to half the height of the absorbance. $\mathrm{pH}$ curve is equal to $\mathrm{pK}$.

The $\mathrm{pK}$ value is given by relation:

$$
\mathrm{pK}=\mathrm{pH}\left(\text { at } \mathrm{A}_{1 / 2}\right)
$$

Where:

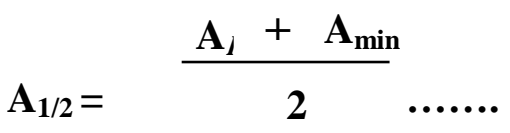

\section{C- Computational Methods}

Theoretical calculations were performed on hyperchem program version 7.5, running on a Pentium V PC-CPU 3400GHz. The geometries of the four compounds were optaimized first at level $(\mathrm{MM}+)$ by molecular mechanics force field theory and then at level (AM1) by semi- empirical theory $^{(20)}$.

\section{Result and Discussion}

In this paper, we describe the synthesis two azo dys compounds from 4-amino-N-2pyrimidinyl-benzenesulfonamide \& 4-amino-N-(5methyl-3-isoxazolyl)- benzenesulfonamide with 4acetaminophenol, were formed in good yield, and its stable at room temperature and are nonhygroscopic. The azo dyes were determined by elemental analysis for $\mathrm{C}, \mathrm{H}$ and $\mathrm{N}$. The results obtained are shown in table (1). A reasonable agreement between the found and calculated data was found. The electronic absorption spectra of the azo dyes (I and II) were recorded at room temperature using Ethanol as solvent (Figures 5and $6)$. The absorption spectra of azo dyes display two bands at $(445,475) \mathrm{nm}$ respectively due to $\left(n-\pi^{*}\right)$ transition of azo bond also which can be assigned to electron delocalization over whole molecule [21]. The all bands were show in figure 2. The IR spectra of the prepared azo dyes show the stretching vibration of the $v(\mathrm{OH})$ groups which appeared in the region (3188-3411) $\mathrm{cm}^{-1}$. The band shows broad appearance due to its relatively low frequency. It can be concluded that the $\mathrm{OH}$ groups may form a hydrogen bond with nitrogen atom and overlap with the stretching vibration of the $v$ ( NH-) group which appeared broad band at ( 3480 ) $\mathrm{cm}^{-1}$. The band $v(\mathrm{~N}=\mathrm{N})$ stretching vibration which appeared in the region (1430-1450) $\mathrm{cm}^{-1}$, other bands with this region can be considered as skeletal vibrations, the $(\mathrm{C}=\mathrm{C})$ stretching vibration of the aromatic ring shows a strong band in the region (1510-1590) $\mathrm{cm}^{-1}$ and the phenolic (C-O) stretching vibration showed a strong band in the region (1100-1200) $\mathrm{cm}^{-1}$ [22]. Other characteristics bands in each individual IR spectra of the prepared compounds are shown in Table (2), representative IR spectra of the azo dyes prepared are shown in Figures 7 and 8 . 
Table(1): Analytical and physical data of the compounds (I and II).

\begin{tabular}{|c|c|c|c|c|c|c|c|}
\hline \multirow{2}{*}{$\begin{array}{c}\text { Azo dye } \\
\text { Compounds }\end{array}$} & \multirow[t]{2}{*}{ Color } & \multirow{2}{*}{$\begin{array}{c}\text { M.P or } \\
\text { dec. temp }\end{array}$} & \multirow{2}{*}{$\begin{array}{l}\lambda \max (n m) \\
\text { in Ethanol }\end{array}$} & \multirow[t]{2}{*}{ Yield (\%) } & \multicolumn{3}{|c|}{ Calculated (Found)(\%) } \\
\hline & & & & & $\mathbf{C}$ & $\mathbf{H}$ & $\mathbf{N}$ \\
\hline I & Brown & $249-251$ & 445 & 78 & $\begin{array}{c}52.33 \\
(52.42)\end{array}$ & $\begin{array}{c}3.54 \\
(3.91)\end{array}$ & $\begin{array}{c}20.25 \\
(20.37)\end{array}$ \\
\hline II & Brown & $183-185$ & 475 & 92 & $\begin{array}{c}51.88 \\
(52.04)\end{array}$ & $\begin{array}{c}4.06 \\
(4.12)\end{array}$ & $\begin{array}{c}16.11 \\
(16.85)\end{array}$ \\
\hline
\end{tabular}

Table (2): IR data for prepared compounds ( I and II)

\begin{tabular}{|c|c|c|c|c|}
\hline \multirow{2}{*}{$\begin{array}{c}\text { Azo dye } \\
\text { compounds }\end{array}$} & \multicolumn{4}{|c|}{ Wave numbers $\left(\mathrm{cm}^{-1}\right)$} \\
\cline { 2 - 5 } & $\begin{array}{c}\text { vo-H } \\
m\end{array}$ & $\begin{array}{c}v C=C \\
m\end{array}$ & $\begin{array}{c}v N=N \\
s\end{array}$ & $\begin{array}{c}\text { v } C \text { - } H \\
m\end{array}$ \\
\hline \multirow{2}{*}{ I } & $3188-3402$ & $1560-1590$ & 1430 & 3091 \\
\hline II & $3196-3411$ & $1510-1530$ & 1450 & 3050 \\
\hline
\end{tabular}

br:broad, s:sharp, m:medium, w:weak

\section{Absorption Spectra of Azo Dyes in Buffer Solutions:}

The absorption spectra of $8 * 10^{-5} \mathrm{M}$ solutions of azo dyes in buffer solutions of varying $\mathrm{pH}$ values (1-12) are represented graphically in figure (2). The spectra of dye (I and II) are characterized by two absorption bands absorbing maximally at $\lambda$ $\max (370$ and 445)nm for I and (420 and 500)nm for II. The shorter wavelength band appearing at low $\mathrm{pH}$ values $(\mathrm{pH}<4)$, this band is due to the absorption of the protonated form whereas the longer wave length band observed at higher $\mathrm{pH}$ $(>7)$, due to the ionized species. On increasing the $\mathrm{pH}$ of medium, the absorbance of the shorter wavelength band decreases while that of the longer wavelength band increases due to the complete transformation of the dye molecule to the corresponding anion liable to predominate in alkaline solution as a result of the ionization of hydroxyl groups. The recorded spectra of dyes possess tow isobestic points for azo dye I at $400 \mathrm{~nm}$ and for azo dye II at 420 and 500nm within the $\mathrm{pH}$ range 1-12. These results indicate the existence of the following equilibrium Scheme 1. (ionization of dyes in acidic and basic medium) [19]. 
<smiles>[R]NS(=O)(=O)c1ccc(N=Nc2cc(NC(C)=O)ccc2O)cc1</smiles><smiles>[R][NH2+]S(=O)(=O)c1ccc(N=Nc2cc(NC(C)=O)ccc2O)cc1</smiles><smiles>CC=CC(C)C</smiles><smiles>[R]NS(=O)(=O)c1ccc(N=Nc2cc(NC(C)=O)ccc2[O-])cc1</smiles>

Anionic F orm<smiles>[R][NH2+]S(=O)(=O)c1ccc(N=Nc2cc([NH3+])ccc2O)cc1</smiles><smiles>[R]F</smiles><smiles>CC1=NOC(C)C1</smiles>

Figure 1: Chemical structures of the prepared azo dyes ( I and II ), I=4-Acetaminophenol-[2-(4-Azo)]-N-2pyrimidinyl-benzenesulfonamide, II= 4-Acetaminophenol-[2-(4-Azo)]-N-(5-methyl-3-isoxazolylbezenesulfonamide. 


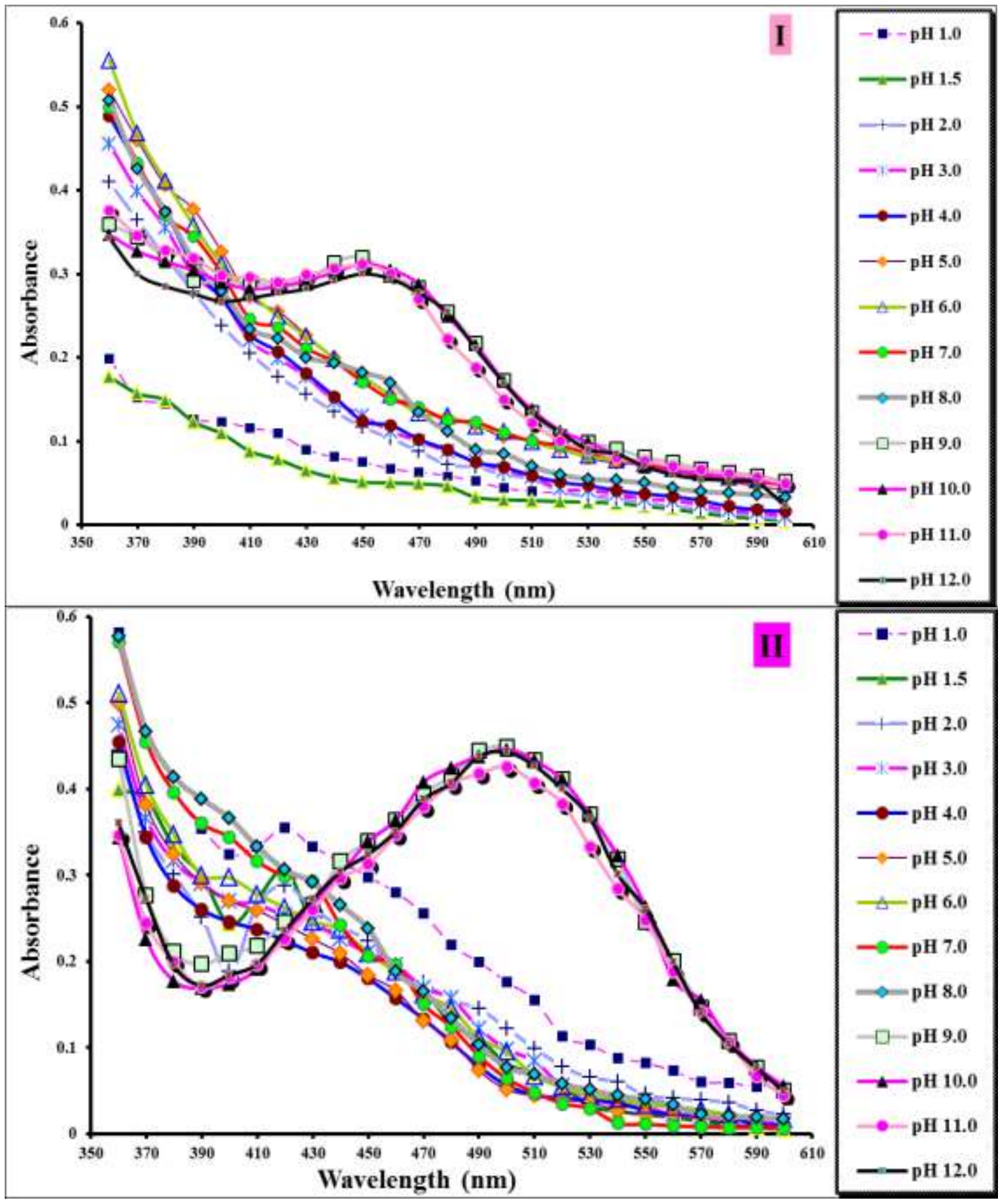

Figure 2: Absorption Spectra of $8 * 10^{-5} \mathrm{M}$ solution of azo dyes (I and II) at varying $\mathrm{pH}$ values

\section{Determination of Ionization and Protonation Constants:}

The ionization and protonation constants of studied azo dyes were determined from the constructed absorbance-pH curves at the selected wavelength as shown in Figure 2 applying the half height method ${ }^{(16)}$. From this method the $\mathrm{pK}$ values are obtained by relations (1and 2). The pk (at $\mathrm{A}_{1 / 2}$ ) was calculated from absorbance-pH curve in Figure (3). The results obtained are given in Table (3) It is clear that the value of pKa of Dyes is in general comparatively high . 
Table (3): Spectrophotometric determination of ionization and protonation constants of azo dyes

\begin{tabular}{|c|c|c|c|c|}
\hline Dye & $p K_{p 1}$ & $p K_{p 2}$ & $p K_{a}$ & $\lambda_{\max }(\mathrm{nm})$ \\
\hline$I$ & 2.25 & 4.5 & 10 & 390 \\
\hline$I I$ & 2.5 & 4.5 & 10.5 & 390 \\
\hline
\end{tabular}

$\mathrm{pK}_{\mathrm{p} 1}=$ Protonation of the first nitrogen atom.

$\mathrm{pK}_{\mathrm{p} 2}=$ Protonation of the second nitrogen atom.

$\mathrm{pK}_{\mathrm{a}}=$ Ionization of the second $\mathrm{OH}$-group.
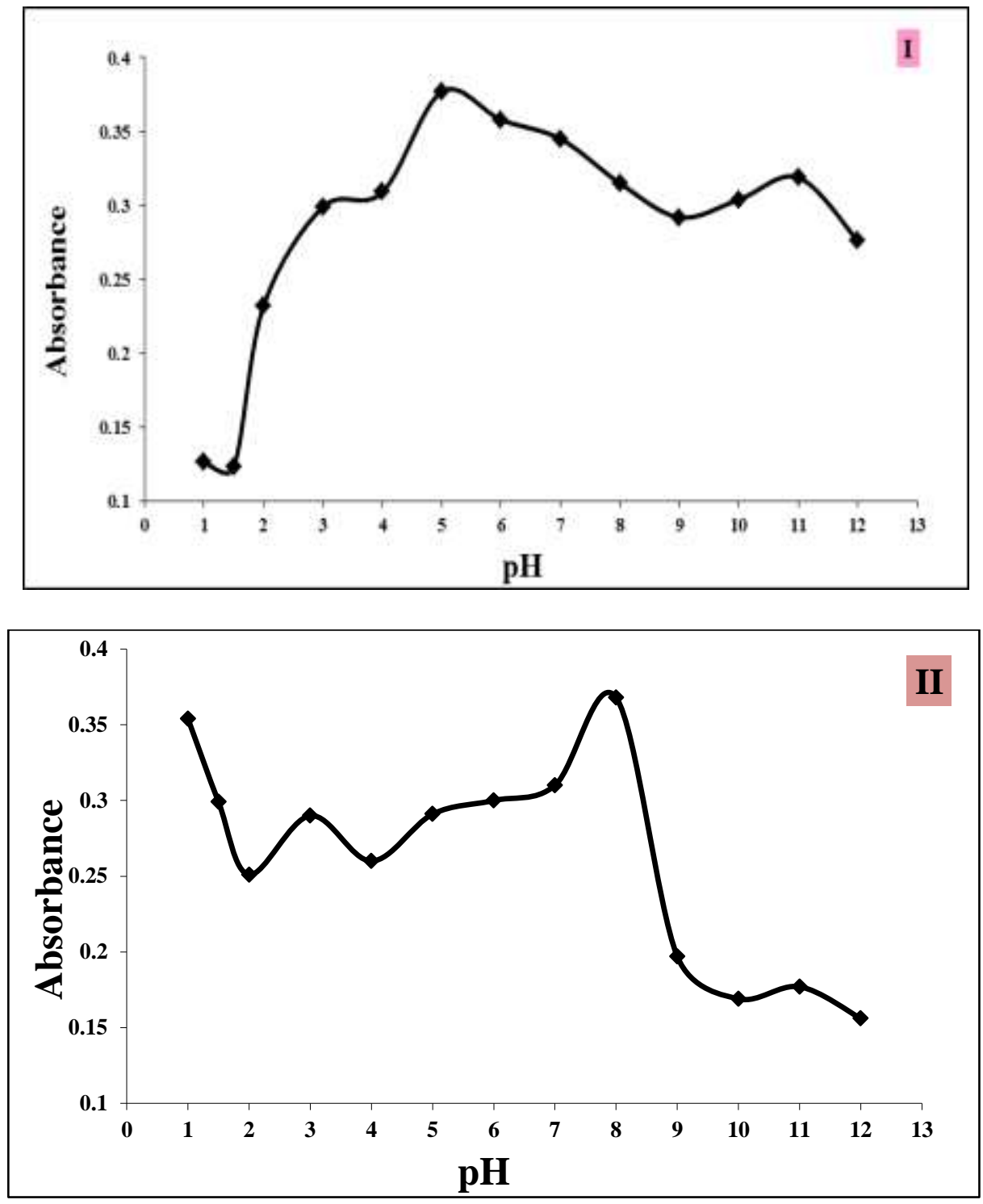

Figure 3: Absorbance - pH curves of Azo compounds ( I and II ) at $\lambda_{\max } 390 \mathrm{~nm}$ 


\section{HyperChem Calculation}

In this work we attempt to study the predication of structure and electronic properties, relative stabilities for the azo dyes. The geometries of the molecules were optimized first by using the molecular mechanics $(\mathrm{MM}+)$ force field, where the lowest energy conformations are obtained, figure
4. The final optimized geometries were obtained by performing the semi-empirical molecular orbital theory at the level of the PM3 of theory. The optimized geometries are shown in figure 4.this figure illustrates the geometry of the molecules in the sticks model ${ }^{(20)}$. Table(4); shows some of molecular information about azo dyes under study.
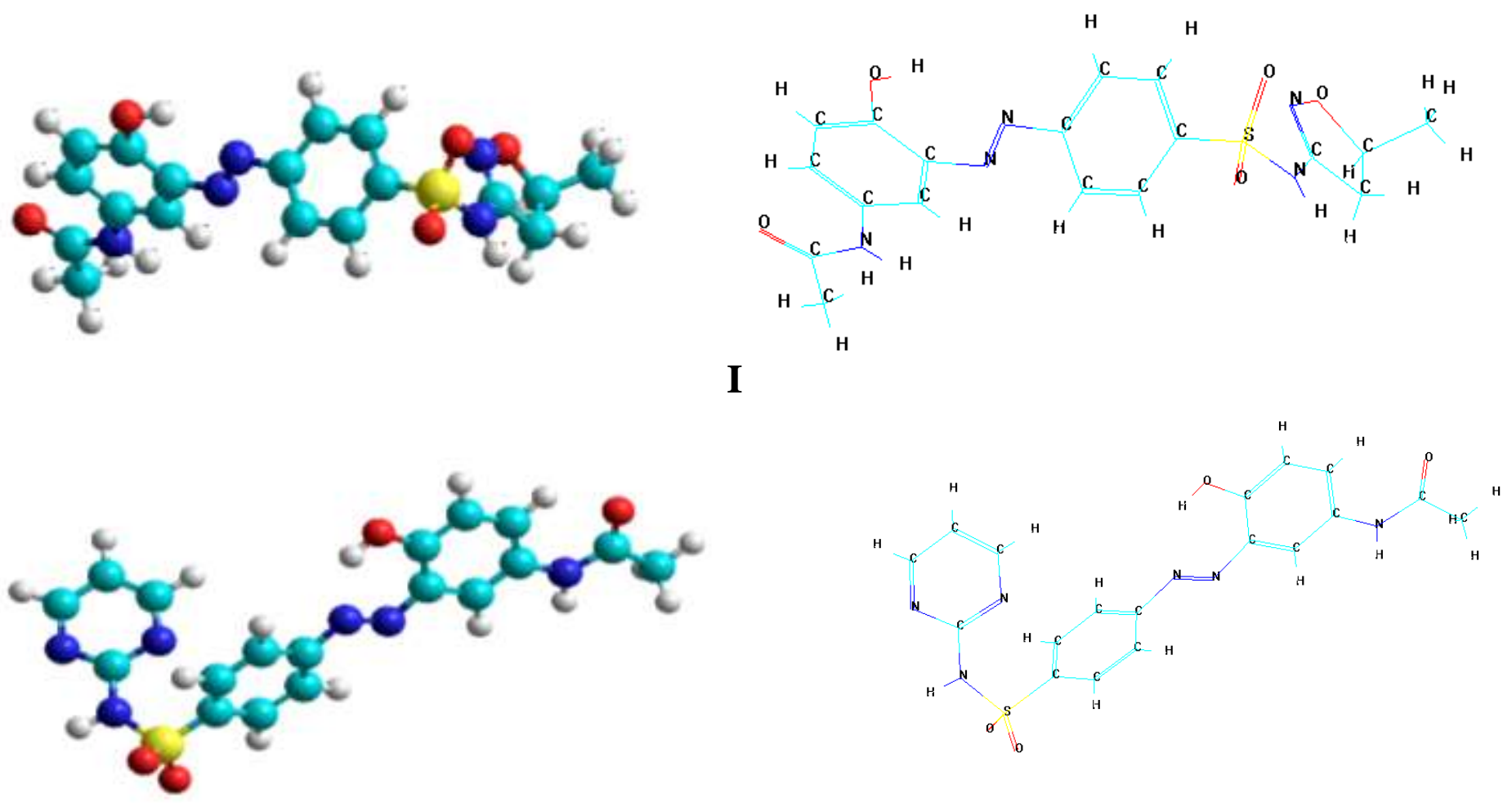

II

Figure 4: The balls and sticks model by using Semi-empirical PM3 calculated optimized structure of azo dyes (I and II) of the possible geometry of azo dye under study in gas phase.

HOMO, Table (4): Calculated Total energy, Heat of formation in kcal/mol and The MO energy of LUMO levels, $\Delta E($ in $\mathrm{eV})$, the dipole moment $\mu$ (in Debye)

\begin{tabular}{|c|c|c|c|c|c|c|}
\hline $\begin{array}{c}\text { Azo } \\
\text { dyes }\end{array}$ & Total energy & $\begin{array}{c}\text { Heat of } \\
\text { formation }\end{array}$ & HOMO & LUMO & $\begin{array}{c}\text { Dipole } \\
\text { (Debye) }\end{array}$ & $\Delta E$ \\
\hline$I$ & -120819.1172 & 14.74713 & -9.0977 & -1.6424 & 5.393 & -7.4553 \\
\hline$I I$ & -124373.7188 & -26.72668 & -8.8528 & -1.6326 & 5.763 & -7.2202 \\
\hline
\end{tabular}




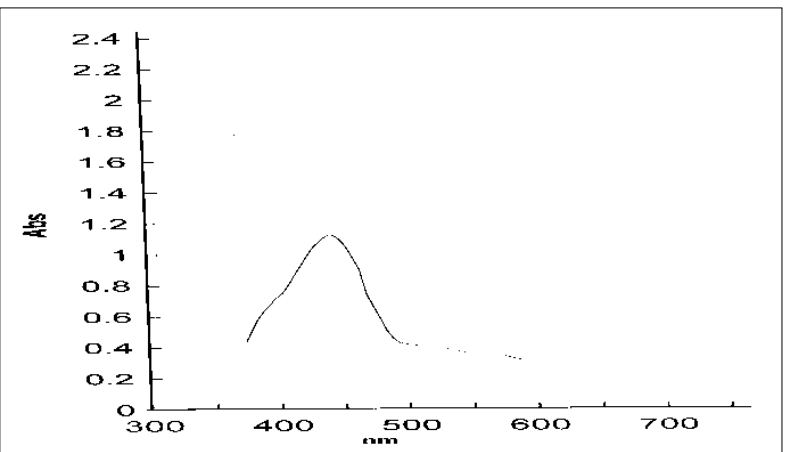

Figure 5: Visible spectra of azo dye (I ) in Ethanol $\left(8 \times 10^{-5}\right) \mathrm{M}$

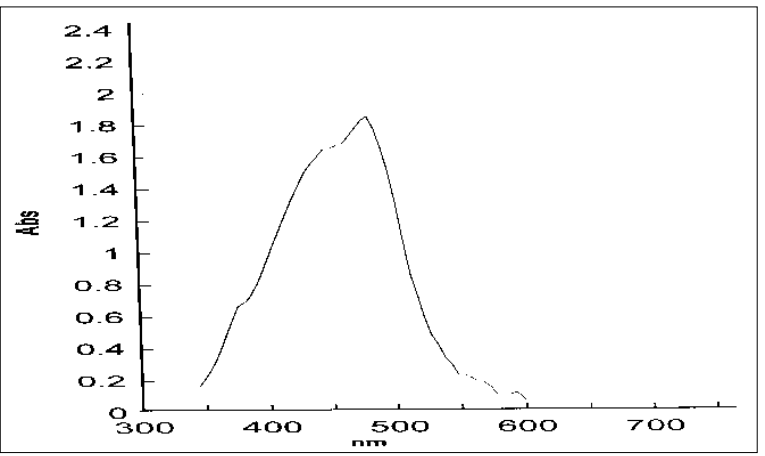

Figure 6: Visible spectra of azo dye ( II ) in Ethanol $\left(8 \times 10^{-5}\right) \mathrm{M}$

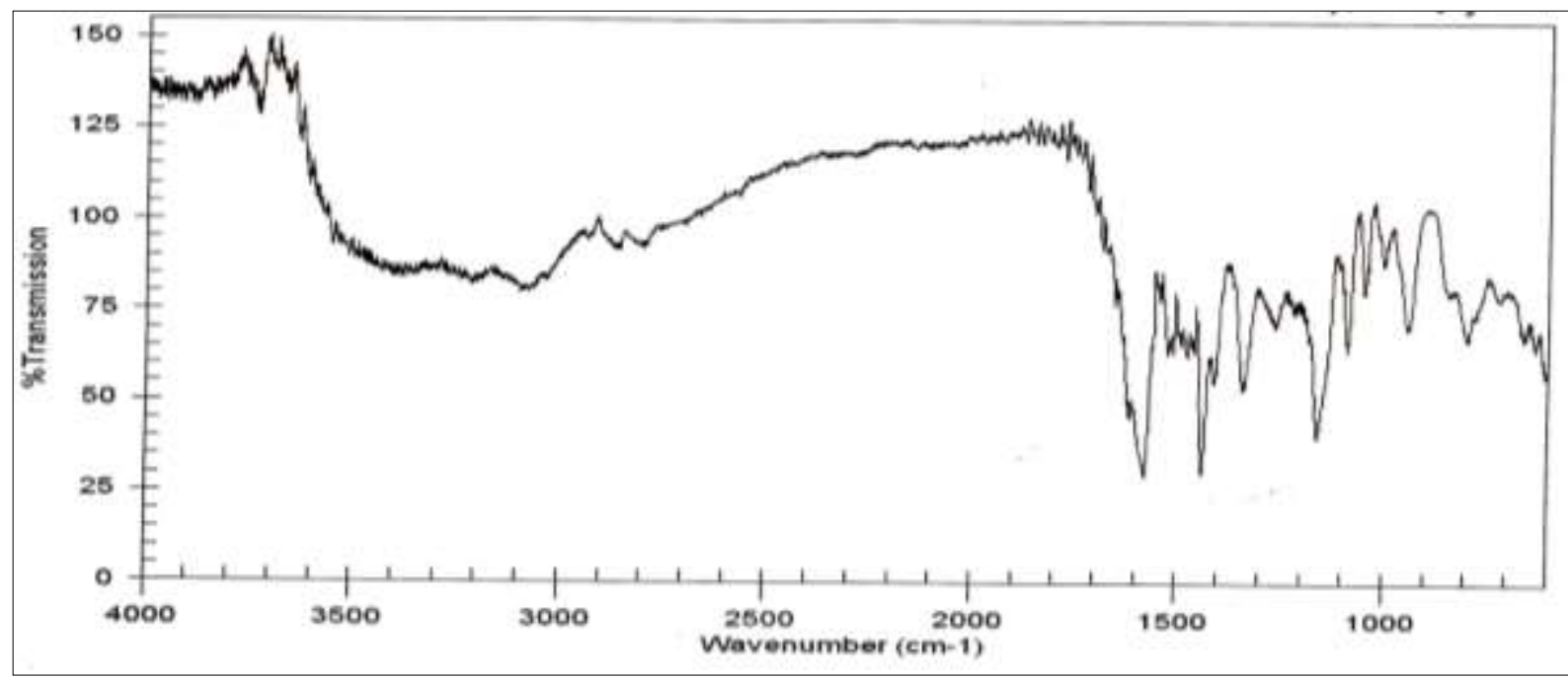

Figure 7: IR-spectrum of Azo dye I

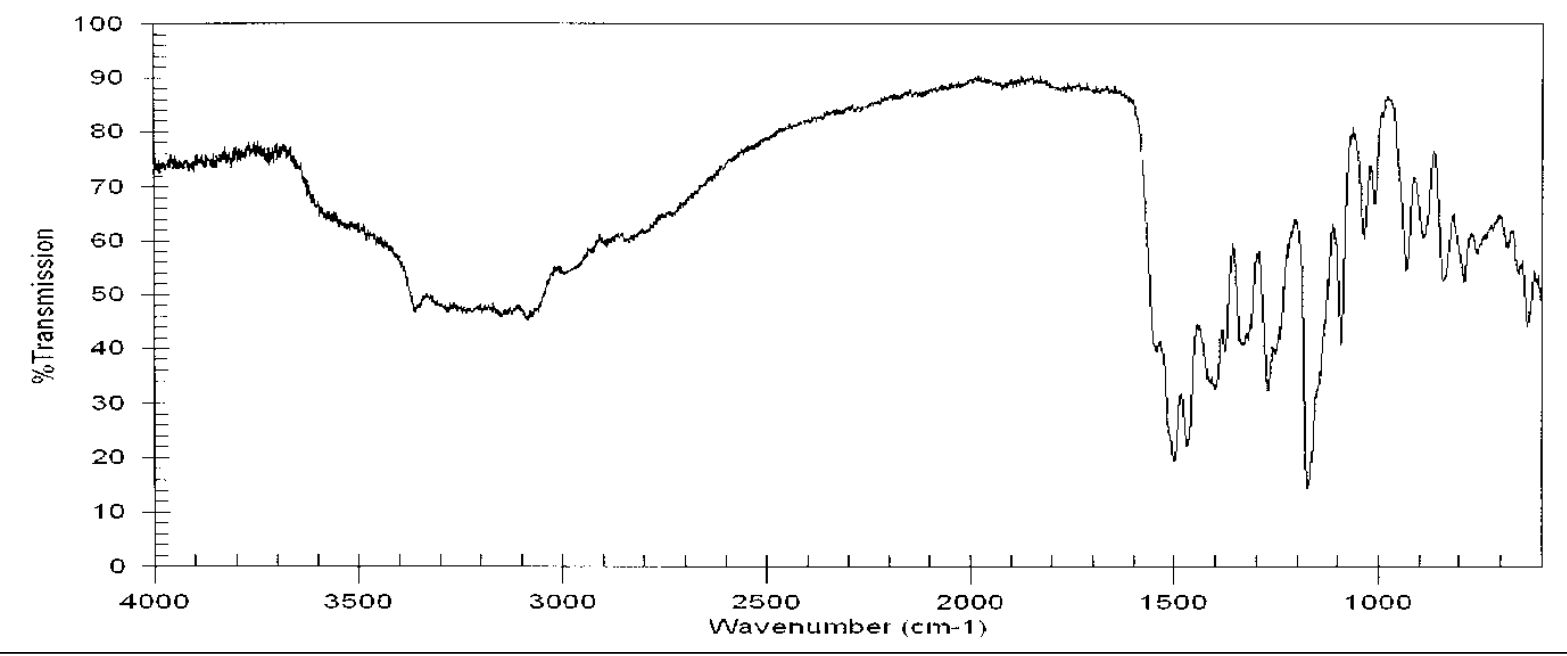

Figure 8: IR-spectrum of Azo dye II 


\section{Reference}

1. F. Yuan and Z.P. Cai, Chines. Chem.Lett 11, 1130-1136, (2003).

2. M. Severino and H. Miranda,. Spectrochim. Acta. 61, 345-353, (2004).

3. D. Netz and W. Sillern, Chem. Rev. 176, 1872-1880, (1999).

4. D. Merg and S. Bonyi., Chem. Phys. Lett. 377, 456, (2007).

5. T. Stewart and J. Bunki, J.Am. Chem.Soc. 165, 312-317, (2003).

6. L. Change and T. Root, J. Am. Chem. Soc. 126, 12, (2004).

7. M. Lee and Z. Medaik, Chem. Mater. 15, 2766-2773,(2008).

8. R. Serreno and D. Lydenst, Coord. Chem. Rev. 276, 195-223,( 2007).

9. A. Hudson and P. Nejy. Acta. Chem. Slov. 56, 833-842,(2006).

10. M.J.L. Dewer, E.G. Zoebisch, E.H. Healy and J.J. D. Stewart, J. Am. Chem. Soc., 177, 3994, (2006) .

11. Ed. K. B. Lipkowitz and D. B. Boyd, "Reviews in Computational Chemistry Volume 6".Ed.K.H. Lipkowitz and D. B. Boyd, VCH,(2006).

12. W. L. F. Armarego and D. D . Perrin, Purification of Laboratory Chemicals ,101,208,(1998).

13. J. J, Fox, J. Chem. Soc , 97, 1339, (1910).

14. A.A.Ali ,T.A.Fahad and I.K.Moammod. Journal of Basrah Researches ((Sciences)),37, 131-140,(2010).

15. W. Tunali and N. Freedy., J. Indian Chem. Soc., 87, 556,(2001).

16. K. Yoo and G. Zevani, Chem. Rev. 98, 982-994,(2005).

17. H. Zollinger, Color Chemistry, Properties and Application of Organic Dyes and Pigments, VCH ,(1991).

18. A. Cheo and J. Marteze., J. Phys. Chem. 265, 2321,(2006).

19. R . Gup and E. Giziroglu, spectro chim Acta. A 65, 719, (2006).

20. Ed. K. B. Lipkowitz and D. B. Boyd, "Reviews in Computational Chemistry Volume 6".Ed. K.H. Lipkowitz and D. B. Boyd, VCH,(2006).

21. Y. R. Sharma," Elementary Organic Spectroscopy ", (2009)India.

22. K . Nakanish and P.Solomon ." Infrared Absorption Spectroscopy" . HOLDEN -DAY , Inc., London , Sydeny, (1977). 